\title{
Keberadaan Bakteri Pasca Aplikasi Biosida di Tambak Pemeliharaan Udang Vaname (Litopenaeus vannamei)
}

\section{The Presence of Bacteria after Biocide Application in Vaname (Litopenaeus vannamei) Shrimp Ponds}

\author{
Bambang Widigdo ${ }^{1}$, Niken TM Pratiwi ${ }^{1}$, \& Firdausa Febi Alfaris ${ }^{1}$ \\ ${ }^{1}$ Departemen Manajemen Sumberdaya Perairan, Fakultas Perikanan dan Ilmu Kelautan, Institut Pertanian \\ Bogor. Jl. Agatis, Kampus IPB Darmaga, Bogor, 16680 \\ Email: widigdo@apps.ipb.ac.id
}

Memasukkan: Oktober 2020, Diterima: Desember 2020

\begin{abstract}
The intensive implementation of the vaname shrimp (Litopenaeus vannamei) operational system causes a high content of organic matter which can lead to a high population of pathogenic bacteria, such as Vibrio sp. This can be controlled through the application of biocides to eradicate all types of bacteria, followed by the application of probiotics to increase the abundance of good bacteria. This study aims to estimate the impact of biocide application on the abundance of bacteria in the vaname shrimp (Litopenaeus vannamei) rearing pond in Tunggal Jaya Village, Sumur District, Pandeglang Regency, Banten. Observations were made in shrimp rearing ponds with different ages (day of care/DOC). Those were $<50$ days (initial DOC), 50-90 days (middle DOC), and $>90$ days (final DOC). The results showed that the abundance of total bacteria (TBC) and Vibrio sp. (TVC) tends to be higher than before biocide application. Biocides can decrease the abundance of TBC one day after application. Probiotics can increase the TBC population and suppress TVC. The relationship between COD and bacterial abundance showed that TBC had a more negative correlation with increasing age (DOC), while TVC remained positive. These results indicate that a single application of biocides is not effective in the abundance of TVC but needs to be combined with the application of probiotics.
\end{abstract}

Keywords: bacteria, biocide, pond water quality

\begin{abstract}
ABSTRAK
Penerapan sistem pemeliharaan udang vaname (Litopenaeus vannamei) secara intensif menyebabkan tingginya kandungan bahan organik yang dapat memicu tingginya populasi bakteri patogen, yaitu Vibrio sp. Hal tersebut dapat dikendalikan melalui aplikasi biosida untuk membasmi seluruh jenis bakteri, dan diikuti aplikasi probiotik untuk meningkatkan kelimpahan bakteri baik. Penelitian ini bertujuan menduga dampak aplikasi biosida terhadap kelimpahan bakteri di kolam pemeliharaan udang vaname (Litopenaeus vannamei) di Desa Tunggal Jaya Kecamatan Sumur, Kabupaten Pandeglang, Banten. Pengamatan dilakukan pada kolam pemeliharaan udang dengan umur (day of care/DOC) berbeda, yaitu $<50$ hari (DOC awal), 50-90 hari (DOC tengah), dan $>90$ hari (DOC akhir). Hasil penelitian menunjukkan bahwa kelimpahan bakteri total (TBC) dan Vibrio sp. (TVC) cenderung lebih tinggi dari sebelum aplikasi biosida. Biosida dapat menurunkan kelimpahan TBC satu hari setelah aplikasi. Pemberian probiotik dapat meningkatkan populasi TBC dan menekan TVC. Hubungan antara COD dengan kelimpahan bakteri menunjukkan bahwa TBC berkorelasi semakin negatif seiring peningkatan umur pemeliharaan (DOC), sedangkan TVC tetap positif. Hasil tersebut menunjukkan bahwa aplikasi tunggal biosida tidak efektif pada kelimpahan TVC, namun perlu dikombinasikan dengan penerapan probiotik.
\end{abstract}

Kata Kunci: bakteri, biosida, kualitas air tambak

\section{PENDAHULUAN}

Bakteri selalu dijumpai dalam perairan tambak udang (Utami dkk. 2016). Terdapat dua kelompok besar bakteri, yaitu yang menguntungkan karena berperan sebagai dekomposer bahan organik (probiotik) dan yang merugikan karena dapat mengganggu kesehatan udang. Keberadaan dan peran kedua bakteri tersebut sangat dipengaruhi oleh pengelolaan operasional tambak, sesuai dengan sistem yang diterapkan.

Operasional pemeliharaan udang dengan sistem intensif menjadi salah satu cara untuk meningkatkan produksi udang. Namun, tingginya jumlah udang dapat menyebabkan tingginya risiko kemunculan penyakit pada udang (Hossain et al. 2008), seperti yang diakibatkan oleh bakteri Vibrio sp. (Suwoyo \& Mangampa 2010), 
sehingga merugikan (Shanmugasundaram dkk. 2015). Bakteri yang tergolong sebagai bakteri gram negatif tersebut tidak hanya menyebabkan penyakit dan bersifat patogen saat memiliki kelimpahan lebih dari $10^{4} \mathrm{CFU} / \mathrm{mL}$ (Kharisma \& Manan 2012), melainkan juga menjadi kompetitor bagi bakteri probiotik yang dibutuhkan untuk menjaga kualitas air tetap ideal.

Bakteri probiotik berperan penting dalam mendekomposisi bahan orgnaik menjadi nutrien melalui berbagai proses dan tahapan tergantung pada senyawa yang didekomposisi, oleh bakteri yang sesuai dengan jenis dan capaian fraksi materi yang terbentuk. Sebagai contoh, terdapat kelompk bakteriamonifikasi, nitrifkasi, dan lainlain. Kelompok bakteri amonifikasi diketahui merupakan bakteri yang dominan ditemukan di sedimen mangrove Pulau Dua (Iswantari dkk 2014). Kondisi yang demikian tidak lepas kondisi kelimpahan bakteri anaerob dan aerob (Agustiyani dkk 2010). Pada penelitian yang dilakukan Badjoeri et al. (2010) di lahan tambak juga menunjukkan bahwa bakteri penghasil amonium merupakan bakteri dengan kelimpahan tertinggi yang ditemukan di sedimen.

Oleh sebab itu untuk pengelolaan media hidup udang supaya tetap ideal sangat diperlukan (Biggs et al. 2005) untuk menumbuhkan bakteri probiotik dan menekan peningkatan bakteri yang bersifat merugikan dan patogen oportunis. Bakteri merugikan, seperti Vibrio sp. tumbuh optimal dan menjadi lebih patogen ketika salinitas air menurun (Arta et al. 2009) dan bahan organik menumpuk dalam perairan. Oleh karena itu, keberadaan bakteri probiotik sangat penting untuk mendekomposisi bahan organik, untuk menekan keberadaan bakteri merugikan, melalui pengontrolan kualitas air.

Pengontrolan keberadaan bakteri dapat dilakukan menggunakan biosida atau pun antibiotik. Biosida merupakan bahan aktif untuk membunuh bakteri secara keseluruhan, sedangkan antibiotik membunuh bakteri secara spesifik (IFH 2000); namun, bakteri gram negatif lebih tahan terhadap antibiotik (Nurmala 2015). Oleh sebab itu diperlukan aplikasi biosida yang tepat yang diikuti dengan pemantauan kualitas air yang baik, sehingga pengaruh aplikasi biosida terhadap pertumbuhan bakteri di kolam dapat dikontrol. Pemantauan kelimpahan bakteri dapat dilakukan melaui penghitungan kelimpahan bakteri Vibrio sp. (TVC/total vibrio count) maupun bakteri total (TBC/total bacteria count) untuk mendapatkan gambaran keberadaan kedua kelompok bakteri.

Keberadaan bakteri yang sangat berkaitan dengan kandungan bahan oranik dalam air akan memiliki pola tertentu dengna adanya aplikasi biosida. Dalam hal ini, diharapkan bahwa biosida tersebut dapat mengontrol kelimpahan bakteri merugikan sehingga penyakit udang yang disebabkannya dapat dicegah. Berkaitan dengan hal tersebut, penelitian ini bertujuan untuk mendeskripsikan keberadaan bakteri pasca aplikasi biosida di tambak pemeliharaan udang vaname (Litopenaeus vannamei).

\section{BAHAN DAN CARA KERAJA}

Penelitian dilakukan dalam dua tahap, yaitu tahap persiapan dan penelitian utama. Tahap persiapan dilakukan pada tanggal 6-10 Mei 2019 di Laboratorium Produktivitas dan Lingkungan Perairan (Proling), Departemen Manajemen Sumberdaya Perairan, Fakultas Perikanan dan Ilmu Kelautan, Institut Pertanian Bogor. Penelitian utama dilakukan pada 1 Juli sampai 23 Oktober 2019 di kolam pemeliharaan udang vaname (Litopenaeus vannamei), Kecamatan Sumur, Kabupaten Pandeglang, Banten (Gambar 1).

Tahap persiapan dimaksudkan untuk memastikan media yang tepat dalam pengujian penumbuhan bakteri Vibrio sp. (TVC) dan

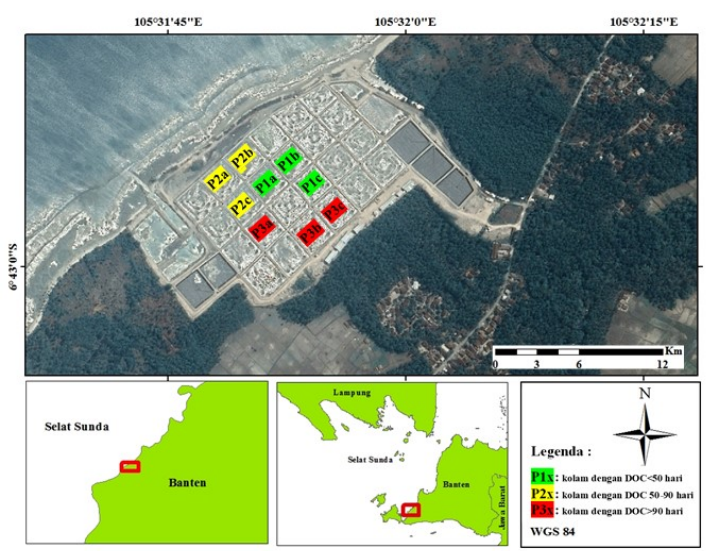

Gambar 1. Lokasi penelitian di tambak Kecamatan Sumur 
bakteri total (TBC) melalui metode tuang. Media kultur untuk TVC yang dimaksud adalah media Thiosulfate Citrate Bile Salt Sucrose Agar (TCBSA), sedangkan untuk TBC adalah media Plate Count Agar (PCA) (Aryal 2019).

Hasil yang diperoleh dalam tahap persiapan adalah bahwa bakteri dapat tumbuh dalam media kultur dan larutan pengencer yang digunakan, dan koloni dapat dihitung menggunakan metode tuang yang diterapkan sengan satuan akhir (CFU/mL) (Sukmawati \& Hardianti 2018). Hal tersebut digunakan dalam kegiatan penelitian utama.

Pada karya ini penelitian utamanya dimaksudkan untuk menentukan perbedaan dampak dari penerapan biosida pada tiga penggal umur pemeliharaan udang (DOC/day of culture) terhadap kelimpahan TBC dan TVC. Selama pemeliharaan juga dilakukan penambahan probiotik untuk meningkatkan populasi bakteri baik dalam kolam pemeliharaan. Penelitian dilakukan pada petak kolam pemeliharaan yang mewakili tiga penggal DOC, yang masing-masing terdiri dari tiga petak. Hal ini dimaksudkan untuk mendapatkan informasi keberadaan bakteri dalam satu siklus pemeliharaan sesuai dengan standar operasional yang diterapkan.

Penelitian dipersiapkan dengan rancangan acak lengkap (RAL) in time (Mattjik \& Sumertajaya 2013) terhadap ketiga penggal DOC, yaitu awal (kurang dari 50 hari), tengah (50-90 hari), dan akhir (lebih dari 90 hari). Pengamatan bakteri dilakukan setiap hari selama delapan hari untuk setiap penggal DOC tersebut. Pengamatan dilakukan pada hari ke-0 (sebelum aplikasi biosida), kemudian dilanjutkan pada hari ke-1 hingga ke-7 setelah aplikasi biosida. Data kontrol dalam penelitian ini berasal dari hasil pengamatan pada siklus sebelumnya yang tidak dilakukan aplikasi biosida, namun dengan operasional kolam yang sama.

Perlakuan aplikasi biosida (campuran bioenzim dan surfaktan) dilakukan dengan konsentrasi $0,5 \mathrm{ppm}(\mathrm{v} / \mathrm{v})$, pada pukul 17.00 WIB, setiap tujuh hari pada jam yang sama. Sebagai catatan, antara hari ke-1 hingga hari ke -7, dilakukan penambahan probiotik komersial setiap tiga hari secara bergantian antara bakteri genus Bacillus sp. dan Thiobacillus sp. dengan konsentrasi 0,015 ppm (w/v).

Pengukuran dan pengambilan contoh air dilakukan dalam waktu yang teratur sebagai berikut. Setiap hari dilakukan dua kali pengukuran terhadap $\mathrm{pH}, \mathrm{DO}$, suhu, dan kecerahan, dan satu kali pengukuran salinitas. Selanjutnya, setiap empat hari dilakukan pengambilan contoh air untuk pengukuran ammonia, nitrit, nitrat, ortofosfat, alkalinitas, dan COD (APHA 2012). Pengambilan contoh harian dilakukan untuk bakteri.

Berdasarkan data kelimpahan bakteri dilakukan penyajian grafik untuk mendapatkan gambaran mengenai pola kelimpahan bakteri TBC dan TVC selama tujuh hari setelah aplikasi biosida. Selanjutnya sidik ragam (ANOVA) RAL in time (Mattjik dan Sumertajaya 2013) digunakan untuk menilai perbedaan pola kelimpahan bakteri antarpenggal DOC.

\section{HASIL}

Nilai pengukuran kualitas air tersebut menunjukkan kondisi yang masih dalam kisaran toleransi udang vaname (Tabel 1). Nilai salinitas, DO, dan $\mathrm{pH}$ berada dalam kisaran

Tabel 1. Kualitas air kolam pemeliharaan udang vaname selama pengamatan

\begin{tabular}{lccc}
\hline Parameter & Rata-rata & $\begin{array}{c}\text { Batas } \\
\text { optimum }\end{array}$ & Acuan \\
\hline Suhu $\left({ }^{\circ} \mathrm{C}\right)$ & $26,8 \pm 0,5$ & $26-32$ & Suwoyo \& Mangampa (2010) \\
DO (mg/L) & $5,1 \pm 0,5$ & $3,0-6,4$ & sda \\
Salinitas (ppt) & $37,1 \pm 2,0$ & $32-42$ & sda \\
pH & $8,0 \pm 0,2$ & $7,3-8,5$ & sda \\
DO (mg/L) & $5,1 \pm 0,5$ & $3,0-6,4$ & sda \\
Amonia-N (mg/L) & $0,16 \pm 0,15$ & $<0,4$ & Widanarni et al. $(2010)$ \\
Nitrit-N (mg/L) & $0,25 \pm 0,34$ & $<4,5$ & sda \\
Nitrat-N (mg/L) & $0,44 \pm 0,34$ & $0,4-0,8$ & Clifford III $(1998)$ \\
Alkalinitas (mg/L CaCO 3$)$ & $131,6 \pm 25,5$ & $100-150$ & Kilawati \& Maimunah $(2015)$ \\
\hline
\end{tabular}


yang memenuhi standar bagi kebutuhan hidup udang (Boyd 1989; Suwoyo \& Mangampa 2010). Kondisi amonia-N, nitrit-N $\left(\mathrm{NO}_{2}\right)$, nitrat$\mathrm{N}\left(\mathrm{NO}_{3}\right)$, ortofosfat, dan alkalinitas perairan tergolong tidak mengganggu pertumbuhan udang (Widanarni dkk. 2010; Syafaat dkk. 2012, Putri dkk. 2019). Berikutnya, nilai standar alkalinitas yang baik berdasarkan Standar Nasional Indonesia 01-7246-2006 adalah 100$150 \mathrm{mg} / \mathrm{L}$. Alkalinitas juga berfungsi sebagai penyedia unsur kalsium untuk kebutuhan osmoregulasi sel tubuh udang (Kilawati \& Maimunah 2015).

Hasil pengamatan bakteri menunjukkan bahwa kelimpahan rata-rata TBC dan TVC selama penerapan aplikasi biosida disajikan ada Gambar 2a dan 2b. Tampak bahwa, pada umumnya kelimpahan TBC lebih tinggi dari TVC. Hal tersebut mengindikasikan tumbuhnya berbagai jenis bakteri di dalam kolam pemeliharaan, selain TVC. Namun, pada kondisi tertentu, kelimpahan TVC mendekati TBC. Aplikasi biosida dapat mempengaruhi keberadaan bakteri selama pemeliharaan. Kelimpahan bakteri sebelum dan saat aplikasi biosida disajikan pada Gambar 3 (TBC) dan Gambar 4 (TVC).

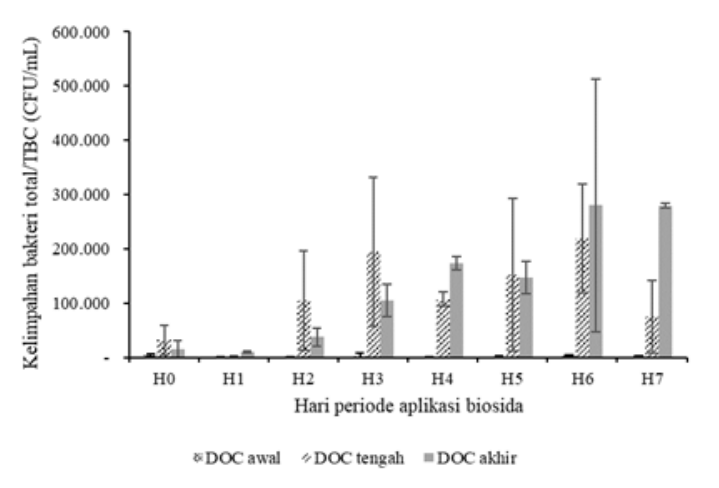

Terlihat bahwa seiring dengan bertambahnya DOC, kelimpahan TBC pada kolam tanpa biosida menurun. Hal sebaliknya terjadi pada kolam dengan aplikasi biosida. Masing-masing penggal DOC menunjukkan pola penurunan yang cenderung sama, yang diduga merupakan pengaruh aplikasi biosida setiap tujuh hari terhadap TBC.

Kelimpahan TVC pada kolam pemeliharaan tanpa aplikasi biosida meningkat seiring meningkatnya DOC. Peningkatan tersebut diduga terjadi ketika populasi bakteri kompetitor memiliki kelimpahan yang rendah. Berbeda dari TBC, aplikasi biosida memberikan dampak peningkatan populasi TVC yang ditunjukkan dengan kelimpahan yang lebih tinggi daripada ketika tidak mendapatkan aplikasi biosida.

Aplikasi biosida dimaksudkan untuk menurunkan kelimpahan bakteri secara menyeluruh. Hal tersebut ditunjukkan oleh keberadaan populasi pada hari ke-0 (sebelum apliaksi), serta ke-1, dan ke-7 setelah aplikasi biosida, melalui ilustrasi pada Gambar 5. Berdasarkan Gambar 5 terlihat bahwa telah terjadi penurunan yang nyata dari TBC setelah aplikasi biosida ( $\mathrm{p}<$ 0,05 ), namun tidak demikian halnya dengan

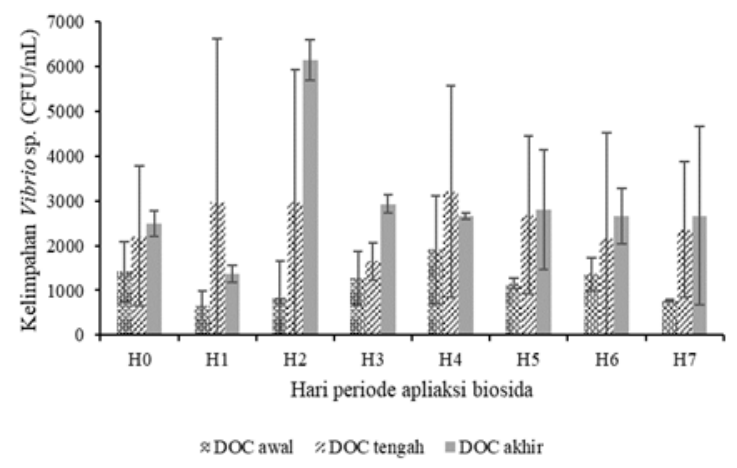

(b) $(\mathrm{CFU} / \mathrm{mL})$ selama apliasi biosida

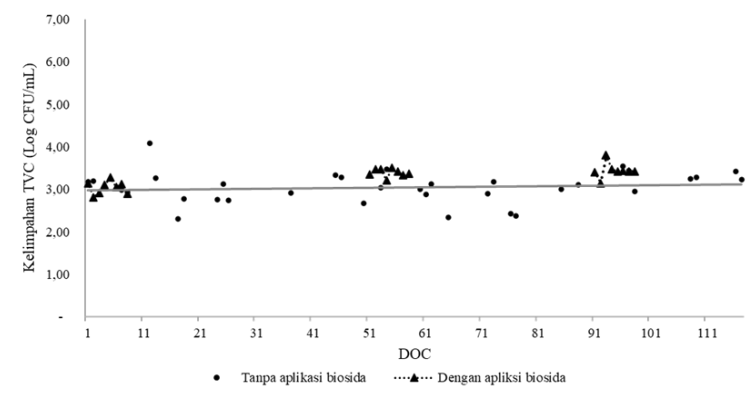

Gambar 4: Kelimpahan TVC sebelum dan saat aplikasi biosida 
TVC $(\mathrm{p}>0,05)$. Selanjutnya, berdasarkan Gambar 6 tampak bahwa perubahan kelimpahan bakteri sebelum aplikasi biosida (hari ke-0) dan sebelum aplikasi biosida kembali (hari ke-7) tidak signifikan $(\mathrm{p}>0,05)$, baik pada TBC maupun TVC. Lebih lanjut lagi, apabila disimak berdasarkan penggal DOC, terlihat perbedaan yang nyata $(\mathrm{p}<0,05)$ pada pola pertumbuhan bakteri antarpenggal DOC, baik pada TBC maupun TVC (Gambar 7a). Kelimpahan TBC meningkat dengan cepat pada hari ke-2 setelah

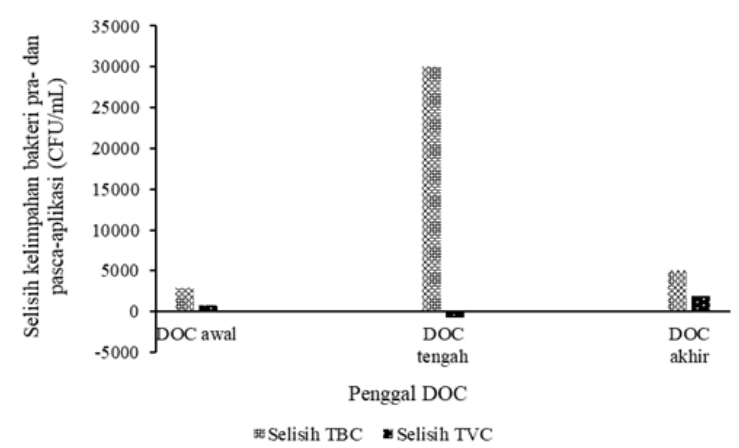

Gambar 5: Selisih kelimpahan antara hari ke-0 dan hari ke-1 pada TBC dan TVC

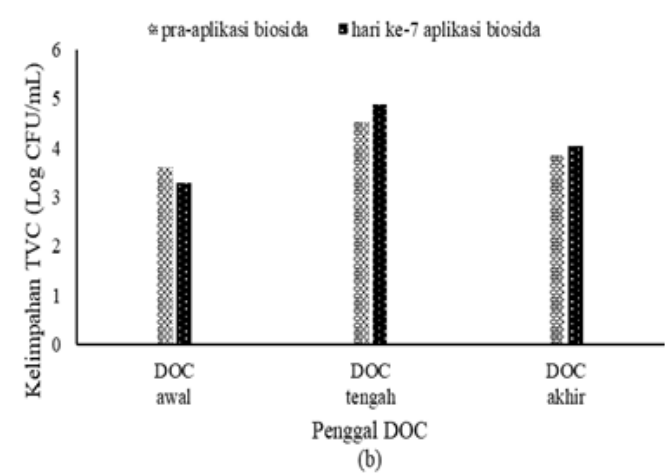

aplikasi biosida, namun menjadi lambat setelah itu. Meskipun demikian, terdapat perbedaan kelimpahan TBC yang nyata dari hari ke hari $(\mathrm{p}<0,05)$. Hal berbeda terjadi pada TVC (Gambar $7 b)$ yang tidak menunjukkan perbedaan kelimpahan yang nyata dari hari ke hari $(\mathrm{p}>0,05)$.

\section{PEMBAHASAN}

Keberadaan TBC memiliki keterkaitan yang erat dengan COD. Pada penggal DOC awal, TBC memiliki krelasi dengan COD sebesar 0,5064, pada penggal DOC tengah sebesar -0,7676. Pada penggal DOC akhir sebesar -0,8162 (Tabel 2). Nilai negatif tersebut

Tabel 2 Hubungan antara COD (X) dengan kelimpahan TBC dan TVC (Y) pada ketiga penggal DOC

\begin{tabular}{lcc}
\hline & TBC & TVC \\
\hline OC awal & $\mathrm{y}=794,41 \mathrm{e}^{0,0012 \mathrm{x}}$ & $=883,15 \mathrm{e}^{0,0004 \mathrm{x}}$ \\
& $\mathrm{R}^{2}=0,4558$ & $\mathrm{R}^{2}=0,38$ \\
OC tengah & $\mathrm{y}=5 \mathrm{E}+07 \mathrm{e}^{-0,007 \mathrm{x}}$ & $J=273,2 \mathrm{e}^{0,0018 \mathrm{x}}$ \\
& $\mathrm{R}^{2}=0,4122$ & $\mathrm{R}^{2}=0,3662$ \\
OC akhir & $\mathrm{y}=4 \mathrm{E}+11 \mathrm{e}^{-0,017 \mathrm{x}}$ & $=1399,7 \mathrm{e}^{0,0006 \mathrm{x}}$ \\
& $\mathrm{R}^{2}=0,5681$ & $\mathrm{R}^{2}=0,9986$ \\
\hline
\end{tabular}

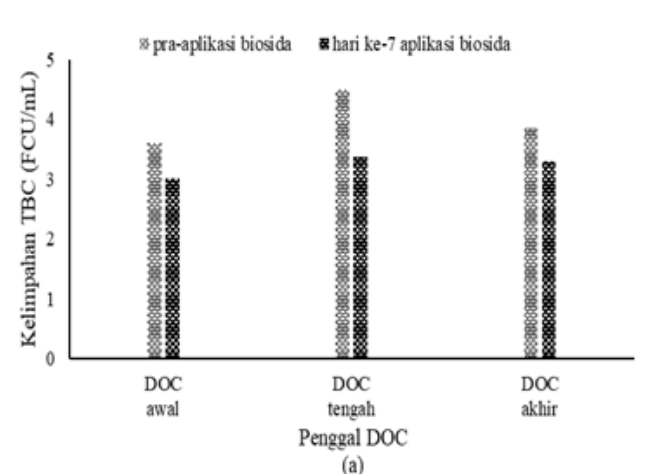

(a)

Gambar 6. Kelimpahan (a) TBC dan (b) TVC hari ke-0 dan hari ke-7
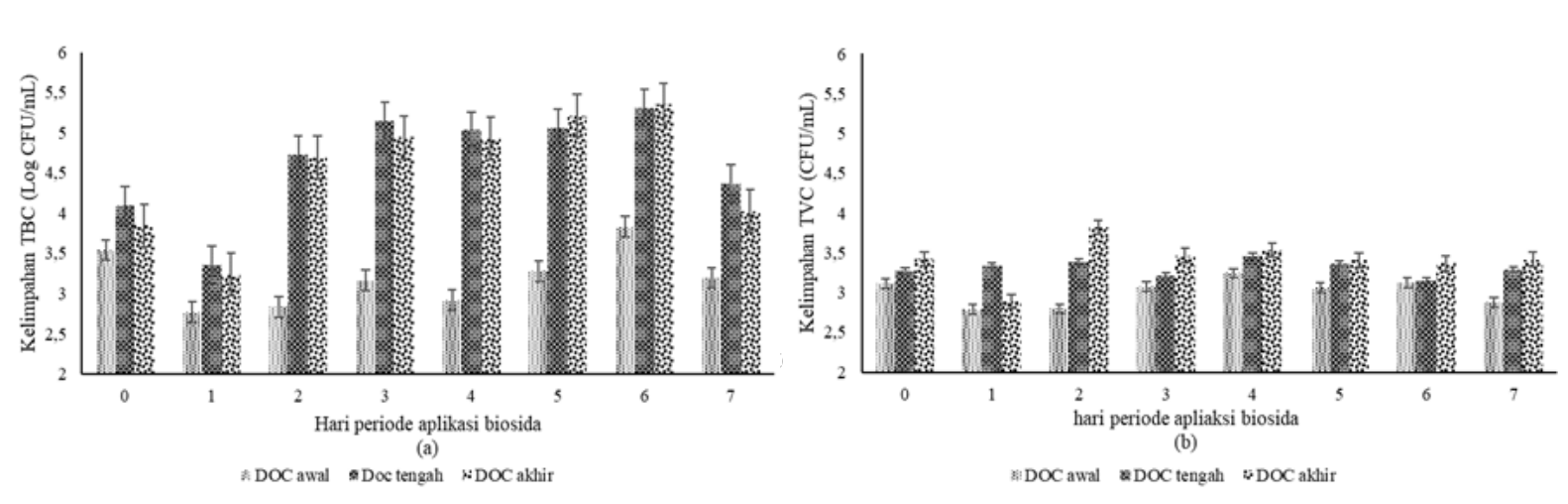

Gambar 7. Pola pertumbuhan bakteri TBC (a) dan TVC (b) selama aplikasi biosida 
meningkat seiring peningkatan DOC.

Korelasi yang ditunjukkan antara kelimpahan TVC dan nilai COD antarpenggal DOC selalu bernilai positif, yaitu sebesar 0,6217 ; 0,6872 ; dan 0,9993 untuk masing-masing penggal DOC. Dengan demikian, setiap peningkatan nilai COD diikuti dengan meningkatnya kelimpahan TVC.

Secara umum, kualitas air kolam pemeliharaan udang cukup menunjang kehidupan udang. Dengan demikian diharapkan bahwa keberadaan bakteri yang dikaji berada dalam media hidup yang memadai bagi udang saat dilakukan aplikasi biosida. Aplikasi biosida yang dilakukan, dimaksudkan untuk mengendalikan pertumbuhan bakteri patogen pada aktivitas pemeliharaan udang vaname agar tidak melewati batas aman keberadaan di perairan.

Selama pengamatan, salinitas yang tinggi di perairan kurang memungkinkan bagi TVC untuk menyerang udang, sebagaimana yang diutarakan oleh Utami dkk. (2016). Pada penelitian ini ditunjukkan bahwa salinitas yang tinggi dapat menekan kelimpahan TVC.

Keberadaan oksigen selama pengamatan relatif sesuai bagi kehidupan bakteri. TVC merupakan bakteri yang juga bersifat heterotrof sehingga membutuhkan oksigen untuk proses hidupnya (Kunarso 1988). Kandungan oksigen yang terukur selama penelitian menunjukkan nilai yang memadai bagi kehidupan bakteri heterotrof tersebut. Keberadaan oksigen didukung oleh proses fotosintesis mikroalgae (Arta et al. 2009) dan juga oleh difusi oksigen mealui operasional kincir (Boyd 1998).

Keberadaan bakteri, termasuk TVC, dipengaruhi oleh suhu. Suhu perairan saat dilaksanakan penelitian berkisar antara 25,2$28,1^{\circ} \mathrm{C}$. Kondisi demikian tidak terlalu mendukung pertumbuhan TVC karena kondisi suhu ideal bagi pertumbuhan TVC adalah 35$36^{\circ} \mathrm{C}$ (Arta et al. 2009). Namun, bakteri ini akan menjadi lebih patogen sehingga lebih berbahaya ketika suhu perairan turun secara drastis (Kharisma \& Manan 2012). Dan, secara umum, kondisi perairan yang tidak stabil juga dapat menyebabkan TVC menjadi lebih patogen terhadap udang (Hatmati 2003).

Ketahanan udang dan pertumbuhan bakteri patogen dipengaruhi oleh kestabilan $\mathrm{pH}$ air. Kondisi $\mathrm{pH}$ perairan yang teramati berada pada batas yang wajar dan tidak terlalu fluktuatif bagi bakteri, dengan kisaran 7,5-8,7 (7,8 $\pm 0,15)$. TVC tumbuh cepat pada perairan dengan kondisi kualitas air yang fluktuatif dan terlalu dinamis (Kharisma \& Manan 2012).

Aplikasi biosida berpengaruh terhadap performa bakteri. Pada perlakuan tanpa aplikasi biosida, kelimpahan bakteri TBC semakin rendah seiring pertambahan DOC, namun pada TVC terjadi hal yang sebaliknya. Peningkatan kelimpahan TVC menunjukkan bahwa bakteri tersebut memiliki performa yang baik ketika kondisi kualitas air tidak stabil dan dengan kandungan bahan organik yang tinggi, sebagaimana yang diutarakan oleh Kharisma \& Manan (2012). Hal demikian mengindikasikan bahwa bakteri selain TVC, yang merupakan kompetitor bagi TVC, mengalami penurunan populasi, sehingga meningkatkan peluang bertumbuh bagi TVC. Hal demikian sesuai dengan temuan Gunarto et al. (2009). Namun, ketika kelimpahan TBC terus meningkat karena dilakukan aplikasi biosida, kelimpahan TVC dapat ditekan. Meningkatnya kompetisi antara TVC dengan TBC dalam memanfaatkan bahan organik memungkinkan terjadinya hal tersebut (Gunarto 2008).

Aplikasi biosida yang digunakan untuk memusnahkan seluruh bakteri yang ada di dalam perairan berfungsi dengan baik, yang tampak pada keesokan harinya, yaitu bahwa kelimpahan TBC yang terdapat di dalam perairan mengalami penurunan secara signifikan. Biosida tergolong cepat dalam membunuh seluruh jenis bakteri, yang berbeda dari antibiotik yang cenderung lebih selektif dalam membunuh biota targetnya. Bakteri yang menerima dampak biosida akan mati secara efektif, tergantung pada jenisnya.

Aplikasi biosida yang tidak dapat menurunkan kelimpahan TVC diduga terjadi karena kandungan bahan organik sangat tinggi pada sistem pemeliharaan yang intensif (Kharisma \& Manan 2012), serta kurangnya efektivitas biosida terhadap bakteri gram negatif (Russell 1999). Namun jika diperhatikan dari hasil aplikasi biosida yang dilakukan setiap tujuh hari, terlihat bahwa bakteri harus dikurangi lagi setelah tujuh hari. Hal ini ditunjukkan dengan perbedaan kelimpahan bakteri 
yang nyata antara hari ke-0 atau sebelum aplikasi biosida dengan hari ke-1 setelah aplikasi, serta kelimpahan yang tidak signifikan antara hari ke- 0 dengan kelimpahan pada hari ke-7 setelah aplikasi biosida.

Hasil tersebut menunjukkan bahwa jadwal aplikasi biosida tersebut sudah sesuai dengan yang seharusnya, yaitu setiap tujuh hari. Aplikasi biosida dengan jadwal yang salah dapat berisiko akan munculnya strain baru yang lebih resisten atau tahan terhadap biosida tersebut. Oleh karena itu, aplikasi biosida harus dilakukan secara hati-hati dan penuh tanggung jawab agar tidak merusak lingkungan. Beberapa hal yang perlu diperhatikan adalah ukuran dosis yang sesuai dan tujuan apliaksi yang jelas (IFH 2000).

Kelimpahan TBC yang mengalami penurunan berpeluang mengalami peningkatan kelimpahan kembali, yakni ketika kelimpahan TBC relatif rendah, sementara bahan organik melimpah, sehigga kompetisi antarbakteri dalam komunitas tersebut rendah. Hal tersebut memicu peningkatan populasi bakteri TBC (Dahlan et al. 2017). Peningkatan signifikan pada TBC juga dapat disebabkan oleh aplikasi probiotik yang dilakukan setiap tiga hari. Namun, ketika populasi TBC relatif tinggi, pertumbuhan menjadi cenderung melambat, kemudian stasioner. Hal ini terjadi karena kandungan nutrisi dan energi hanya cukup untuk memenuhi kebutuhan hidup TBC, sehingga setelah tidak memadai, terjadi proses penurunan populasi (Dahlan et al. 2017).

Kelimpahan populasi bakteri paling rendah dijumpai pada penggal DOC awal, baik pada TBC maupun TVC. Seiring dengan peningkatan DOC dan meningkatnya kandungan bahan organik dalam air, bakteri memanfaatkannya untuk pertumbuhan. Meskipun demikian, tetap terjadi penumpukan di dasar kolam karena tidak seluruh bahan organik tersebut termanfaatkan. Penerapan aerator yang memunculkan sirkulasi air yang bahan organik ke bagian tengah kolam dapat memudahkan pengontrolan bahan organik dalam kolam (Rogers 1989) melalui penerapan sifonisasi setiap 1-3 hari. Meskipun demikian, bahan organik masih tetap meningkat seiring bertambahnya usia pemeliharaan udang karena semakin banyak pakan yang ditambahkan dan meningkatnya ukuran udang (Subyakto et al. 2009); sementara, intensitas kegiatan siphon tetap.

Bakteri TBC yang diamati secara harian selama aplikasi biosida menunjukkan penurunan yang drastis sehari setelah apliaksi, namun mengalami pertumbuhan signifikan $(p<0,05)$ pada hari berikutnya. Hal tersebut menunjukkan bahwa efek dari aplikasi probiotik menyebabkan kelimpahan bakteri dapat meningkat signifikan. Hal yang berbeda ditunjukkan oleh TVC yang berfluktuasi setiap hari. Keberadaan TVC yang berfluktuasi tidak menunjukkan keterkaitan dengan kelimpahan pada TBC. Hal tersebut diduga terjadi karena TVC tidak terlalu terpengaruh dan tetap tumbuh dengan baik akibat aplikasi biosida yang kurang efektif terhadap bakteri gram negatif serta tingginya kandungan bahan organik karena sistem operasional pemeliharaan yang intensif (Kharisma \& Manan 2012, Russell 1999).

Bahan organik, yang digambarkan oleh COD, merupakan sumber nutrisi dan energi bagi bakteri (Boyd \& Tucker 1998; Krisnawati \& Hardini 2014). Keterkaitan antara COD dengan kelimpahan bakteri menunjukkan korelasi yang semakin negatif seiring peningkatan DOC. Namun, pada TVC terlihat hasil yang tetap positif. Hal ini mengindikasikan bahwa TVC tidak terpengaruh oleh aplikasi biosida, serta mampu memanfaatkan keberadaan bahan organik untuk tumbuh.

Korelasi antara COD dan kelimpahan TBC yang semakin negatif mennunjukkan bahwa populasi TBC tidak cukup efektif dalam memanfaatkan bahan organik. Sementara, TVC dapat tumbuh baik saat bahan organik tinggi, sehingga tetap memiliki korelasi positif. Namun, kelimpahan TVC dapat ditekan dengan adanya probiotik yang berperan dalam menguraikan bahan organik. Bakteri probiotik yang merupakan bakteri heterotrof dapat berkompetisi dengan Vibrio sp. yang juga bersifat heterogen (Gunarto et al. 2009). Peningkatan populasi probiotik yang bersifat heterotrof tersebut memicu meningkatnya pemanfaatan kandungan bahan organik dalam air. Hal tersebut akan menyebabkan kandungan bahan organik dalam perairan menurun seiring dengan peningkatan kelimpahan bakteri probiotik (Yudiati dkk. 2010). Oleh karena itu, aplikasi probiotik yang efektif dibutuhkan 
untuk dapat menekan keberadaan TVC dalam kolam. Ketika kelimpahan TVC sebagai bakteri patogen dapat ditekan, kesehatan dan pertumbuhan udang akan lebih baik (Supono dkk. 2019).

\section{KESIMPULAN DAN SARAN}

Aplikasi biosida tidak dapat menurunkan kelimpahan TBC dan juga TVC secara sinkron. Aplikasi biosida dapat menurunkan kelimpahan TBC secara langsung satu hari setelah perlakuan, namun tidak terjadi pada TVC. Meskipun demikian, kelimpahan TVC dapat ditekan melalui penambahan aplikasi probiotik.

Biosida yang dapat membunuh bakteri dengan cepat, sebaiknya diapliaksikan secara berhati-hati dan penuh tanggung jawab. Kombinasi aplikasi biosida dan probiotik sebaiknya dilakukan dengan teknik yang lebih efektif untuk menekan populasi TVC

\section{DAFTAR PUSTAKA}

Agustiyani, D., RM. Kayadoe, \& H. Imamuddin. 2010. Oksidasi nitrit oleh bakteri heterotrofik pada kondisi aerobik. Jurnal Biologi Indones. 6(2): 265-275.

Badjoeri, M., YP. Hastuti, T. Widiyanto, \& I. Rusmana. 2010. Kelimpahan bakteri penghasil senyawa amonium dan nitrit pada sedimen tambak sistem semi intensif. Limnotek. 17 (1): 102-111.

Arta, AP., A. Maidie, \& G. Septiani. 2009. Pengaruh kerapatan vegetasi mangrove terhadap populasi bakteri Vibrio sp. di Pesisir Bontang. Jurnal Kehutanan Tropika Humida. 2(2): 133-143.

Aryal, S. 2019. Thiosulfate citrate bile salts sucrose (TCBS) agar composition, principle, uses, preparation and colony morphology. [Internet]. [diunduh 2020 Apr 8]. Tersedia pada: https://microbiology info.com/ thiosulfate-citrate-bile-salts-sucrose-tcbsagar-composition-principle-usespreparation-and-colony-morphology/

Biggs, J., P. Williams, M. Withfield, N. Pascale, \& A. Weatherbi. 2005. 15 years of pond assessment in Britain: results and lessons learned from the work of Pond Conservation.
Aquatic Conservation: Marine and Fresh water Ecosystem (15): 693-714.

Boyd, CE. 1998. Pond water aeration systems. Aquacultural Engineering. 18(1998):9-40.

Boyd, CE, \& CS. Tucker. 1998. Pond Aquaculture Water Quality Management. New York (US): Kluwer Academic Publishers.

Clifford III, HC. 1998. Management of Ponds Stocked With Blue Shrimp Litopenaeus Stylirostirs. In Print, Proceedings of the 1st Latin American Congress on Shrimp Culture, Panama City, Panama, October 1998. http://aquafind.com/articles/mop.php

Dahlan, A, Wahyuni S, Ansharullah. 2017. Morfologi dan karakterisasi pertumbuhan bakteri asam laktat (UM 1.3A) dari proses fermentasi Wikau mambo untuk studi awal produksi enzim amilase. Jurnal Sains dan Teknologi Pangan. 2(4): 657-663.

Frobish, LT. 1989. Water Quality Management and Aeration in Shrimp Farming. Alabama (US): Auburn University.

Gunarto. 2008. Beberapa aspek penting dalam budidaya udang vaname (Litopenaeus vannamei) dengan sistem pemupukan susulan di tambak (tradisional plus). Media Akuakultur. 3(1):15-24.

Gunarto, A. Mansyur, \& Muliani. 2009. Aplikasi dosis fermentasi probiotik berbeda pada budidaya udang vaname (Litopenaeus vannamei) pola intensif. Jurnal Riset Akuakultur. 4(2):241-255.

Hatmati, A. 2003. Penyakit bakterial pada budidaya krustasea serta cara penanganannya. Oseana. 28(3):1-10.

Hossain, MA., ME. Hoq, \& MA., Mazid. 2008. Use of chemicals and biological products in aquaculture in Bangladesh. The Agriculturist. 6(1\&2):29-42.

[IFH] International Scientific Forum on Home Hygiene. 2000. Microbial resistance and biocides. 1-42.

Iswantari, A., Y. Wardiatno, NTM. Pratiwi \& I. Rusmana 2014. Fluks Bentik dan Potensi Aktivitas Bakteri Terkait Siklus Nitrogen di Sedimen Perairan Mangrove Pulau Dua, Banten. Jurnal Biologi Indonesia 10(1): 109-117.

Kharisma, A, \& A. Manan. 2012. Kelimpahan 
bakteri Vibrio sp. pada air pembesaran udang vannamei (Litopenaeus vannamei) sebagai deteksi dini serangan penyakit vibriosis. Jurnal Ilmiah Perikanan dan Kelautan. 4(2):129-34.

Kilawati, Y, \& Y. Maimunah. 2015. Kualitas lingkungan tambak intensif Litopenaeus vannamei dalam kaitannya dengan prevalensi penyakit white spot syndrome virus. Journal of Life Science. 2(1): 23559926.

Krisnawati, A., \& D. Hardini. 2014. Kajian beberapa dekomposer terhadap kecepatan dekomposisi sampah rumah tangga. Buana Sains. 14(2): 79-89.

Kunarso, DH. 1988. Peranan bakteri heterotrofik dalam ekosistem laut. Oseana. 13(4): 133142.

Mainassy, MC. 2017. Pengaruh parameter fisika dan kimia terhadap kehadiran ikan lompa (Thryssa baelama Forsskal) di Perairan Pantai Apui Kabupaten Maluku Tengah. Jurnal Perikanan Universitas Gajah Mada. 19(2): 2502-5066.

MatTjik, AA., \& IM. Sumertajaya. 2013. Perancangan Percobaan dengan Aplikasi SAS dan Minitab. Bogor (ID): IPB Press.

Nurmala. 2015. Pola bakteri, resistensi dan sensitivitasnya terhadap antibiotik berdasarkan hasil kultur pada spesimen pus di Rumah Sakit Umum Dokter Soedarso Pontianak tahun 2011-2013. [Publikasi Ilmiah] Fakultas Kedokteran Universitas Tanjungpura Pontianak.

Putri, WAE., AIS. Purwiyanto, Fauziyah, F. Agustriani, \& Y. Suteja. 2019. Kondisi nitrat, nitrit, amonia, fosfat, dan BOD di muara Sungai Banyuasin, Sumatera Selatan. Jurnal Ilmu dan Teknologi Kelautan Tropis. 11(1):65-74.

Rogers, GL. 1989. Aeration and circulation for effective aquaculture pond management. Aquacultural Engeenering. 8:349-355.

Russell, AD. 1999. Bacterial resistance to disinfectants: present knowledge and future problems. Journal of Hospital Infection. (43):57-68.

Shanmugasundaram, S, P. Mayavu, T. Manikandarajan, M. Suriya, A. Eswar, \& R. Anbarasu. 2015. Isolation and identification of Vibrio sp. in the Hepatopancreas ofcultured white pacific shrimp (Litopenaeus vannamei). International Letters of Natural Sciences. 46: 52-59.

Subyakto, S., D. Sutende, M. Afandi \& Sofiati. 2009. Budidaya udang vannamei (Litopenaeus vannamei) semiintensif dengan metode sirkulasi tertutup untuk menghindari serangan virus. Jurnal Ilmiah Perikanan dan Kelautan. 1(2): 121-127.

Sukmawati, \& F. Hardianti. 2018. Analisis Total Plate Count (TPC) mikroba pada ikan asin kakap di Kota Sorong Papua Barat. Biodjati. 3(1): 72-78.

Supono, HE. Wardiyanto, AH. Khotimah, \& A. Ningtyas. 2019. Identification of Vibrio sp. as cause of white feces diseases in white shrimp Penaeus vannamei and handling with herbal ingredients in East Lampung Regency, Indonesia. AACL Bioflux. 12 (2):417-425.

Suwoyo, HS., \& M. Mangampa. 2010. Aplikasi probiotik dengan konsentrasi berbeda pada pemeliharaan udang vaname (Litopenaeus vannamei). Forum Inovasi Teknologi Akuakultur. 239-247.

Syafaat, MN., A. Mansur, \& S. Tonnek. 2012. Dinamika kualitas air pada budidaya udang vaname (Litopenaeus vannamei) semiintensif dengan teknik pergiliran pakan. Di dalam: Syafaat MN, editor. Dinamika kualitas air pada budidaya udang vaname (Litopenaeus vannamei) semi-intensif dengan teknik pergiliran pakan. Prosiding IndoaquaForum Inovasi Teknologi Akuakultur; 2012; Maros, Indonesia. Maros (ID): Balai Penelitian dan Pengembangan Budidaya Air Payau. 487-493.

Utami, W., Sartijo, \& Desrina. 2016. Pengaruh salinitas terhadap efek infeksi Vibrio harveyi pada udang vaname (Litopenaeus vannamei). Journal of Aquaculture Management and Technology. 5(1):82-90.

Widanarni, F. Rajab, Sukenda, \& M. Setiawati. 2010. Isolasi dan seleksi bakteri probiotik dari lingkungan tambak dan hatcheri untuk pengendalian penyakit vibriosis pada larva udang windu, Penaeus mondon. Jurnal Riset Akua kultur. 5(1): 103-113.

Widowati, R. 2008. Keberadaan bakteri Vibrio 
Widigdo dkk.

parahaemolyticus pada udang yang dijual di rumah makan kawasan Pantai Pangandaran. Vis Vitalis. 1(1): 9-14.

Yudiati, E., Z. Arifin, \& I. Riniatsih. 2010. Pengaruh aplikasi probiotik terhadap laju sintasan dan pertumbuhan tokolan udang vaname (Litopenaeus vannamei), populasi bakteri Vibrio, serta kandungan amoniak dan bahan organik media budidaya. Jurnal Ilmu Kelautan. 15(3): 153-158. 